\title{
LOLOSAN TAJUK, ALIRAN BATANG DAN INTERSEPSI PADA POHON PAKOBA (Syzigium sp.) NANTU (Palaquium obtusifolium Burck) DAN CEMPAKA (Magnolia tsiampacca)
}

\author{
THROUGH FALL, STEM FALL AND INTERCEPTION IN PAKOBA (Syzigium sp.) \\ NANTU (Palaquium obtusifolium Burck) AND CEMPAKA (Magnolia tsiampacca) \\ trees.
}

\author{
Novita I. Rumagit 1), Josephus I. Kalangi2), dan Fabiola B. Saroinsong 2) \\ 1) Mahasiswa S1 Program Studi IImu Kehutanan, Fakultas Pertanian Unsrat Manado, 95115 \\ 2)Staf Pengajar Jurusan Budidaya Pertanian, FakultasPertanian UnsratManado, 95115
}

\begin{abstract}
Interception is one part of hidrology cycle which small value and sometimes ignored but interception has a large impact on certain plants. Amoun of value stem fall and through fall affected by interception. This study was conducted in Tomohon City Forest with purpose to determine magnitude of value through fall, stem fall and interception pakoba (Syzigium Sp.), nantu (Palaquium obtusifolium Burck) and cempaka (Magnolia tsiampacca). This research by using randomized group design method use 3 (tree) type of trees pakoba (Syzigium Sp.), nantu (Palaquium obtusifolium Burck) and cempaka (Magnolia tsiampacca). Each was repeated 5 (Five) times, in order to obtain 15 units of the experiment. Data were analyzed with analysis of variance and further using BNT test. The result of this research show amount of value stem fall pakoba $10,55 \%$, nantu $9,01 \%$ and cempaka 7,99 \%. Amount of value through fall pakoba 8,13 $\%$, nantu $5,25 \%$ and cempaka 2,45 \%. Amount of value interception pakoba $82 \%$, nantu 86,31 $\%$ and cempaka $89,37 \%$. BNT test show interception in pakoba $82 \%$ significant different with cempaka $89,37 \%$ and not significant different with nantu $86,31 \%$. Nantu $86,31 \%$ not significant different with cempaka 89,37\%.
\end{abstract}

Keywords : interception, stem fall, through fall

\begin{abstract}
ABSTRAK
Intersepsi merupakan salah satu bagian dalam siklus hidrologi yang nilainya kecil dan adakalanya diabaikan namun, intersepsi memiliki dampak yang besar pada tanaman tertentu. Besarnya nilai aliran batang dan lolosan tajuk dipengaruhi oleh Intersepsi. Penelitian ini dilakukan di Hutan Kota Tomohon dengan tujuan untuk mengetahui besarnya nilai lolosan tajuk, aliran batang dan intersepsi pohon pakoba (Syzigium Sp.), nantu (Palaquium obtusifolium Burck) dan cempaka (Magnolia tsiampacca). Penelitian ini dilakukan dengan metode rancangan acak kelompok, menggunakan 3 (tiga) jenis pohon yaitu pakoba, nantu dan cempaka. Masing-masing diulang sebanyak 5 (lima) kali sehingga diperoleh 15 (lima belas) satuan percobaan. Data dianalasis dengan analisis sidik ragam dan uji lanjut BNT. Hasil penelitian menunjukkan besarnya nilai lolosan tajuk pakoba 10,55\%, nantu 9,01\% dan cempaka 7,99\%. Besarnya nilai aliran batang pakoba $8,13 \%$, nantu $5,25 \%$ dan cempaka 2,45\%. Besarnya nilai intersepsi pakoba 82 $\%$, nantu $86,31 \%$ dan cempaka 89,37\%. Uji beda nyata terkecil (BNT) menunjukkan intersepsi pada jenis pohon pakoba $82 \%$ berbeda nyata dengan cempaka $89,37 \%$ dan tidak berbeda nyata dengan nantu $86,31 \%$. Nantu $86,31 \%$ tidak berbeda nyata dengan cempaka $89,37 \%$.

Kata Kunci : Intersepsi, Aliran batang, Lolosan tajuk
\end{abstract}

Eugenia Volume 25 No. 2 Juni 2019 


\section{PENDAHULUAN}

Hutan mempunyai fungsi hidrologis yng penting terutama dalam mendistribusikan besaran curah hujan dari atmosfer ke permukaan tanah. Distribusi air hujan ke permukaan tanah akan berubah-ubah dan terjadi variabilitas oleh karena perubahan atau pengurangan tajuk dan tegakannya. Air hujan yang sampai di tajuk pohon ditahan oleh tajuk tersebut dan sebagian menjadi tetesan air hujan yang menerobos tajuk dan akhirnya sampai ke permukaan tanah sebagai lolosan tajuk (throughfall) dan sebagian mengalir melalui batang sebagai aliran batang (stemfall) (Slamet, 2015).

Lolosan tajuk (throughfall) merupakan air hujan yang jatuh langsung ke permukaan tanah melalui ruang antar tajuk juga daun atau menetes melalui daun dan cabang. Sedangkan aliran batang (stemfall) merupakan air hujan yang dalam perjalanannya sampai ke permukaan tanah mengalir melalui batang vegetasi. Lolosan tajuk dan aliran batang merupakan dua proses mekanis dari jatuhnya air hujan dari permukaan tajuk vegetasi sampai mencapai permukaan lantai hutan. Dengan demikian, beda antara curah hujan total dan hasil pertambahan antara lolosan tajuk dan aliran batang disebut intersepsi (Asdak, 2014).

Intersepsi merupakan bagian air hujan yang ditahan dan melekat pada tajuk vegetasi, yang mana sebagian akan menguap ke udara atau diserap oleh vegetasi tersebut dan sebagian air hujan akan menjadi aliran batang dan lolosan tajuk. Intersepsi menyebabkan ada bagian air hujan yang tidak pernah sampai ke permukaan tanah (Arsyad, 2012). Hilangnya air melalui intersepsi merupakan bagian dalam analisis keseimbangan air (water balance) yang berkaitan dengan produksi air (water yield) pada daerah aliran sungai (DAS). Intersepsi sebagai kehilangan air (rainfall interception loss) dalam analisis keseimbangan air. Air hujan yang jatuh di atas vegetasi disebut hujan kotor (gross rainfall), sedangkan air hujan yang mencapai permukaan tanah melalui lolosan tajuk dan aliran batang disebut hujan efektif (net precipitation) (Basri et al, 2012). Intersepsi pada hutan tergantung pada curah hujan, struktur penutupan vegetasi dan jenis vegetasi (Jayanti et al, 2015). Penelitian ini menghitung besarnya intersepsi pada pohon pakoba (Syzygium sp.) nantu (Palaquium obtusifolium Burck) dan cempaka (Magnolia tsiampacca) di Hutan Kota Tomohon. Tanaman yang berbeda akan menghasilkan nilai intersepsi yang berbeda pula.

Tujuan dari penelitian ini adalah untuk mengetahui besarnya nilai lolosan tajuk, aliran batang dan intersepsi pada pohon pakoba (Syzygium sp.) nantu (Palaquium obtusifolium Burck) dan cempaka (Magnolia tsiampacca).

Manfaat dari penelitian ini diharapkan dapat memberikan informasi mengenai pengaruhh jenis pohon dalam mengintersepsi air hujan yang berimplikasi pada konservasi air dan tanah.

\section{METODE PENELITIAN}

Penelitian ini dilaksanakan di Hutan Kota kelurahan Talete satu kota Tomohon dari bulan Agustus-November 2018.

Alat yang digunakan ialah gelas ukur, terpal dan ember penampung curahan tajuk, kaleng dan ember penampung aliran batang, tambang karet, kaleng penampung sebagai alat penakar curah hujan (ombrometer) tipe manual, plastisin, alat ukur diameter batang meteran atau pita ukur, alat pengukur tinggi pohon (klinometer), alat tulis menulis. Bahan yang digunakan adalah pakoba, nantu dan cempaka.

Penelitian ini dilakukan dengan metode rancangan acak kelompok, menggunakan 3 (tiga) jenis pohon yaitu pakoba, nantu dan cempaka. Masing-masing diulang sebanyak 5 (lima) kali sehingga diperoleh 15 (lima belas) satuan percobaan. Data dianalasis dengan analisis sidik ragam dan uji lanjut BNT (Beda Nyata Terkecil).

Variabel yang diamati dan diukur dalam penelitian ini adalah curah hujan $(\mathrm{mm})$, aliran batang $(\mathrm{mm})$, lolosan tajuk $(\mathrm{mm})$, tinggi pohon $(\mathrm{m})$, tinggi bebas cabang $(m)$, diameter batang $(m)$ dan diameter tajuk $(\mathrm{m})$.

\section{Analisis Data}

Data yang di peroleh dianalisis untuk mengetahui nilai intersepsi. Untuk menghitung besarnya nilai intersepsi pada suatu jenis pohon digunakan persamaan berikut (Asdak, 2014) :

$$
I=P g-(T f+S f)
$$

dimana, I adalah intersepsi (mm), Pg adalah curah hujan (mm), Tf adalah Lolosan Tajuk (mm) dan Sf adalah aliran batang $(\mathrm{mm})$. 
Data aliran batang, lolosan tajuk dan intersepsi dianalisis keragamannya menggunakan Analysis of variance (Anova) dan apabila terdapat perbedaan maka akan dilanjutkan dengan uji BNT (Beda Nyata Terkecil).

\section{HASIL DAN PEMBAHASAN}

\section{Lolosan Tajuk}

Gambar 1 menunujukkan rata-rata lolosan tajuk dari 5 (lima) kejadian hujan, lima kejadian hujan tersebut masing-masing $0,7 \mathrm{~mm}, 0,89 \mathrm{~mm}$, $1,27 \mathrm{~mm}$ dan $1,4 \mathrm{~mm}$. Rata-rata lolosan tajuk pakoba $0,13 \mathrm{~mm}$, nantu $0,11 \mathrm{~mm}$ dan cempaka 0,1 $\mathrm{mm}$.

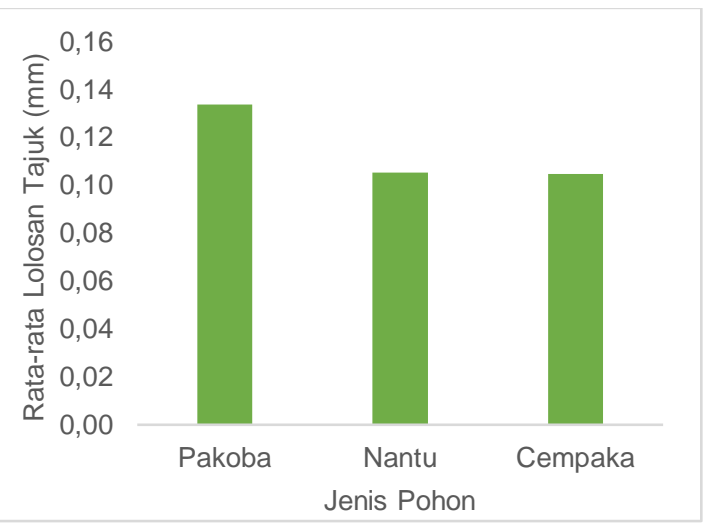

Gambar 1. Rata-rata Nilai Lolosan Tajuk pada Pakoba, Nantu dan Cempaka

Gambar 1 terlihat rata-rata nilai lolosan tajuk terbesar terdapat pada pohon pakoba, kemudian nantu dan terakhir cempaka. Selanjutnya untuk mengetahui apakah terdapat perbedaan signifikan antara ketiga jenis pohon dilakukan uji analisis sidik ragam (anova).

Hasil analisis keragaman menunjukkan bahwa jenis pohon (pakoba, nantu dan cempaka) tidak memberikan pengaruh signifikan terhadap lolosan tajuk atau tidak berbeda nyata ( $F$ hitung $<F$ tabel).

Tabel 1 menunjukkan nilai lolosan tajuk terbesar terdapat pada jenis pohon pakoba yaitu $10,55 \%$ kemudian nantu 9,01\% dan nilai lolosan tajuk terkecil pada cempaka 7,99\%.
Tabel 1. Lolosan Tajuk Pada Pakoba, Nantu dan Cempaka

\begin{tabular}{ccc}
\hline Jenis Pohon & $\begin{array}{c}\text { Persentase } \\
\text { Lolosan Tajuk }\end{array}$ & Notasi \\
\hline Pakoba & $10,55 \%$ & a \\
Nantu & $9,01 \%$ & a \\
Cempaka & $7,99 \%$ & a \\
\hline
\end{tabular}

Keterangan : Notasi yang sama menyatakan tidak ada perbedaan

Semakin bertambah rapat tajuk vegetasi maka semakin berkurang pula air lolosan tajuknya. Pohon dengan tajuk yang kurang rapat menyebabkan air mudah lolos ke permukaan tanah (Asdak, 2014). Pakoba memiliki nilai lolosan tajuk terbesar, pakoba dengan model arsitektur massart dengan pola percabangan plagiotropik yang dikenal dengan sistem percabangan yang bertingkat secara teratur dan menghasilkan tebalnya strata tajuk pohon massart (Arrijani dan Lombok, 2006) namun arah cabang pakoba pada penelitian ini condong keatas menyebabkan tajuk cepat jenuh sehingga air hanya sebagian yang tertahan di tajuk dan sebagian besar jatuh melalui lolosan tajuk, tajuk pakoba yang tumbuh condong ke atas karena pada lokasi penelitian di Hutan Kota Tomohon jarak tanam pakoba rapat sehingga sudut percabangan cenderung condong ke atas. Selain arah cabang yang condong ke atas besarnya nilai lolosan tajuk juga disebabkan tajuk pakoba yang kurang rapat membuat pohon ini banyak terdapat celah sehingga air hujan langsung menembus tajuk dan lolos ke permukaan tanah.

Nantu termasuk dalam model arsitektur attim dikenal dengan pola percabangan orthotropik dengan sudut percabangan yang sempit dari arah tumbuhnya ke batang pohon menyebabkan tajuk cepat jenuh dengan air (Arijani dan Lombok, 2006) namun, pada penelitian di Hutan Kota Tomohon nantu memiliki pertumbuhan cabang berbeda dari pakoba yang condong ke atas sedangkan pada nantu mendatar, menyebabkan lebih banyak bagian permukaan tanah yang ditutupi oleh tajuk di mana pohon ini tumbuh. Rata-rata diameter tajuk nantu adalah $5,33 \mathrm{~m}$ dan luas tajuknya 23,68 $\mathrm{m}$ lebih besar dari pakoba yang diameter tajuknya $5,12 \mathrm{~m}$ dan luas tajuk 21,58 m sehingga lebih banyak air yang tertahan pada tajuk nantu dibandingkan 
dengan tajuk pakoba. Daun pohon nantu berukuran panjang $12-30 \mathrm{~cm}$ dan lebar $5-10 \mathrm{~cm}$. Ukuran daun nantu lebih kecil dari pohon cempaka, ukuran permukaan daun dan kerapatan tajuk dapat berpengaruh terhadap besar kecilnya air hujan yang lolos melalui tajuk, daun yang luas dan tajuk yang rapat akan menyebabkan lebih sedikit celah antar daun sehingga air hujan tidak mudah lolos sampai ke permukaan tanah, dengan demikian dapat dikatakan semakin luas ukuran permukaan daun dan semakin rapat tajuk maka semakin besar pula air hujan yang diintersepsikan sehingga lolosan tajuk nilainya kecil dan sebaliknya semakin sempit luas permukaan daun dan semakin kurang rapat tajuk vegetasi maka semakin sedikit pula air yang diintersepsikan sehingga banyak air hujan yang jatuh sebagai lolosan tajuk (Heryansah, 2008).

Cempaka termasuk dalam model arsitektur attim dengan sistem percabangan monopodial sama seperti nantu. Namun dibandingkan nantu dan pakoba, cempaka dengan diameter tajuk dan luas tajuk yang lebih besar, yaitu 6,44 m dan 34,82 $\mathrm{m}$, pohon cempaka juga memiliki daun yang lebih lebar 4-16 cm dan panjang 7-36 cm hal ini menyebabkan lebih banyak permukaan tanah yang ditutupi oleh tajuk karena diameter tajuk, luas tajuk dan daun yang lebih besar daripada pakoba dan nantu sehingga lebih banyak bagian air hujan yang terintersepsi. Oleh karena itu, cempaka memiliki nilai Iolosan tajuk lebih kecil daripada nantu dan pakoba. Penelitian lolosan tajuk pada pakoba, nantu dan cempaka terlihat tajuk ketiga jenis pohon ini tidak jauh berbeda. Tajuk pohon pakoba, nantu dan cempaka memiliki sistem percabangan yang sama yaitu monopodial, sehingga pada hasil analisis keragaman tidak terdapat perbedaan signifikan.

\section{Aliran Batang}

Gambar 2 menunujukkan rata-rata aliran batang dari 5 (lima) kejadian hujan, lima kejadian hujan untuk setiap jenis pohon (pakoba, nantu dan cempaka)

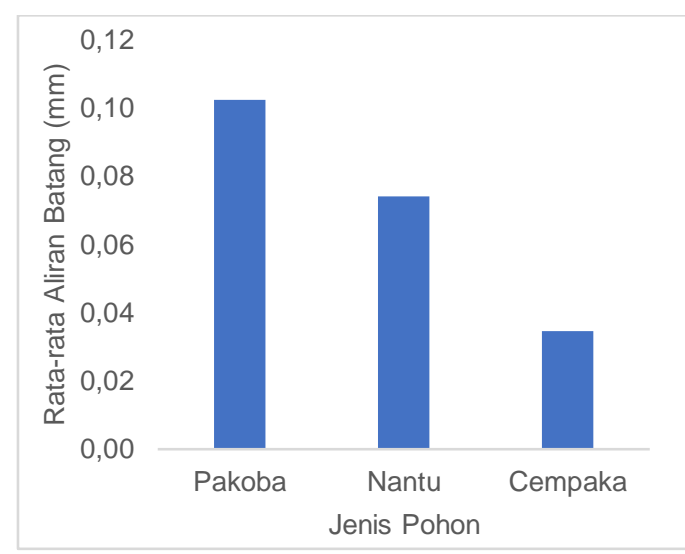

Gambar 2. Rata-rata nilai aliran batang pada pakoba, nantu dan cempaka

Gambar 2 terlihat aliran batang terbesar terdapat pada pohon pakoba $0,10 \mathrm{~mm}$, kemudian nantu 0,07 mm dan terakhir cempaka 0,03 mm. Untuk mengetahui apakah terdapat perbedaan signifikan anatara ketiga jenis pohon dilakukan uji analisis sidik ragam (anova).

Tabel 2. Aliran Batang Pada Pakoba, Nantu dan Cempaka

\begin{tabular}{ccc}
\hline Jenis Pohon & $\begin{array}{c}\text { Persentase } \\
\text { Aliran Batang }\end{array}$ & Notasi \\
\hline Pakoba & $8,13 \%$ & a \\
Nantu & $5,25 \%$ & a \\
Cempaka & $2,45 \%$ & a
\end{tabular}

\section{Keterangan : Notasi yang sama menyatakan tidak ada perbedaan}

Namun analisis keragaman jenis pohon pakoba, nantu dan cempaka terhadap aliran batang menunjukkan $\mathrm{F}$ hitung $<\mathrm{F}$ tabel yang berarti jenis pohon tidak memberikan pengaruh yang nyata terhadap aliran batang Tabel 2. Tabel 2 menunjukkan bahwa nilai aliran batang terbesar pada pakoba yaitu $8,13 \%$ dari curah hujan, kemudian nantu $5,25 \%$ dari curah hujan dan nilai aliran batang terkecil pada cempaka 2,45\% dari curah hujan.

Pakoba dengan model arsitektur massart dengan pola percabangan plagiotropik. Pola percabangan plagiotropik dikenal memiliki nilai aliran batang yang rendah karena percangan tajuknya yang tumbuh bertingkat sehingga tajuk tidak mudah jenuh oleh air (Arijani dan Lombok, 
2006). Namun seperti pada Iolosan tajuk aliran batang pada pakoba juga menunjukkan hal yang sama yaitu nilai aliran batang pakoba lebih besar daripada nantu dan cempaka hal ini karena pakoba memiliki cabang-cabang pohon yang cenderung condong ke atas terlihat bentuknya seperti corong oleh karena pola pertanaman yang rapat sehingga tajuk pohon cenderung bertumbuh ke atas untuk memperoleh sinar matahari, selain itu tajuk pohon pakoba tumbuh tidak lebat dan tidak rapat sehingga tajuk pohon cepat mengalami kejenuhan dan air hujan yang jatuh ke cabang-cabang pohon tersebut sebagian jatuh melalui lolosan tajuk dan sebagian mengalir melalui batang. Besar kecilnya aliran batang pada setiap pohon dipengaruhi oleh keadaan permukaan batang dan percabangannya, semakin baik keadaan permukaan pohon maka semakin banyak air yang jatuh melalui batang pohon tersebut, serta percabangan pohon yang condong mengarah ke bawah menyebabkan air lebih sulit untuk jatuh melalui batang sedangkan percabangan yang mengarah ke atas memudahakan air hujan untuk jatuh melalui batang (Irmas,2010). Pakoba memiliki permukaan yang mulus atau licin sehingga air hujan sangat mudah untuk jatuh melalui batang. Selain dipengaruhi oleh permukaan batang besar kecilnya nilai aliran batang juga dapat dipengaruhi oleh tinggi pohon, semakin tinggi pohon maka semakin rendah nilai aliran batangnya, karena air hujan membutuhkan waktu yang lebih lama untuk mencapai pangkal batang seiring bertambahnya tinggi pohon (Jayanti et al, 2015). Dilihat dari tinggi pohon, pakoba yang diamati pada Tabel 2 memiliki rata-rata tinggi pohon 21,22 $\mathrm{m}$ lebih tinggi dari pohon yang lain seharusnya air hujan lebih sulit untuk sampai ke pangkal batang pohon namun dengan percabangan yang condong ke atas dan permukaan batang yang licin mengakibatkan air hujan sangat mudah jatuh melalui batang pakoba.

Nantu termasuk dalam model arsitektur attim dengan cabang monopodial dan arah cabang mendatar sehingga nilai aliran batangnya lebih kecil dibandingkan dengan pakoba yang arah cabangnya condong ke atas. Rata-rata tinggi nantu $12,00 \mathrm{~m}$ bila dibandingkan dengan pakoba dan cempaka tinggi nantu adalah yang terendah menyebabkan air hujan yang tertampung lebih banyak karena pergerakan air dari tajuk ke ember penampung lebih cepat sehingga aliran batang pada nantu lebih banyak daripada cempaka. Selain itu nantu memiliki permukaan batang yang berlumut sehingga air yang jatuh akan tertahan dan menyebabkan nilai aliran batangnya lebih kecil dibandingkan pakoba.

Cempaka memiliki nilai aliran batang terkecil. Cempaka termasuk dalam model arsitektur attim, sistem percabangan monopodial dan arah cabang mendatar sama dengan nantu. Rata-rata tinggi cempaka 14,94 lebih tinggi dari nantu dan lebih rendah dari pakoba. Berdasarkan tinggi pohon nilai aliran batang cempaka lebih rendah dari pakoba dan nantu. Selain tinggi pohon terlihat permukaan batang cempaka memiliki bekas-bekas cabang sehingga lebih sulit untuk air hujan jatuh melewati permukaan batang cempaka. Selain itu kerapatan tajuk vegetasi dapat mempengaruhi aliran batang, tajuk yang kurang rapat akan menyebabkan air mudah lolos dan jatuh sebagai aliran batang (Asdak, 2014) pada Tabel 2 dapat dilihat tajuk cempaka lebih luas dan rapat dari pada nantu dan pakoba, yaitu dengan diameter tajuk 6,44 $\mathrm{m}$ dan luas tajuknya $34,82 \mathrm{~m}$ menyebabkan air hujan yang jatuh di permukaan tajuk tidak mudah jenuh dan berperan mengurangi besarnya aliran batang pada cempaka. Penelitian aliran batang pada pakoba, nantu dan cempaka, terlihat bahwa karakteristik kulit batang pakoba, nantu dan cempaka berbeda namun perbedaan kulit batang ini tidak berbeda secara signifikan. Menurut Chairani dan Jayanti (2013), salah satu faktor yang mempengaruhi aliran batang adalah bentuk percabangan. Pakoba, nantu dan cempaka memiliki bentuk percabangan yang sama yaitu simpodial sehingga pada hasil analisis keragaman lolosan tajuk tidak ada perbedaan signifikan.

\section{Intersepsi}

Gambar 3 menunujukkan rata-rata aliran batang dari 5 (lima) kejadian hujan untuk setiap jenis pohon pakoba, nantu dan cempaka.

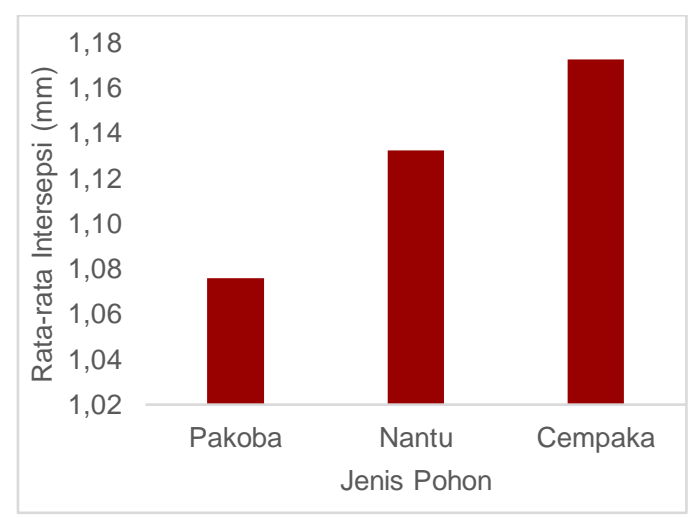

Gambar 3. Rata-rata nilai intersepsi pada pakoba, nantu dan cempaka 
Gambar 3 terlihat intersepsi terbesar terdapat pada pohon cempaka dengan rata-rata $1,17 \mathrm{~mm}$, kemudian nantu 1,13 mm dan terakhir pakoba 1,08 $\mathrm{mm}$. Pada Gambar 4 dapat dilihat tren peningkatan dari pengaruh curah hujan terhadap intersepsi.

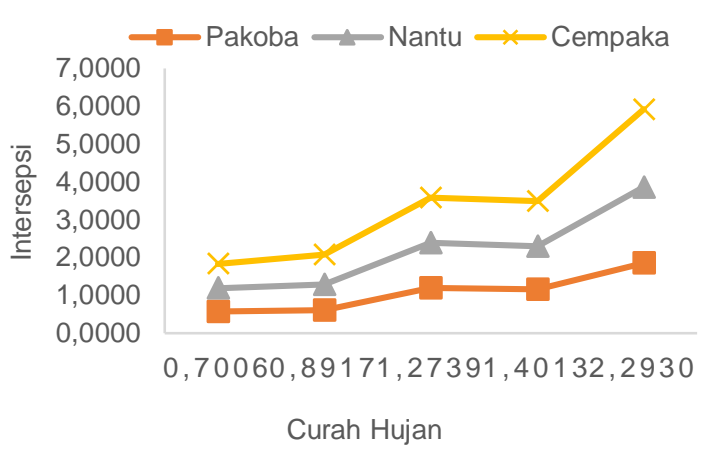

Gambar 4 Pengaruh Curah Hujan terhadap Aliran Batang pada Pakoba, Nantu dan Cempaka

Berdasarkan Gambar 4 intersepsi yang meningkat berbanding lurus dengan peningkatan curah hujan seperti pada penelitian sebelumnya Irmas (2010) menunjukkan hal yang sama yaitu pada pohon kerai payung, karet dan akaisa, curah hujan yang bertambah mengakibatkan bertambah pula nilai intersepsinya. Penelitian Jayanti et al (2013) intersepsi pada pohon jati dan pinus juga menunjukkan hubungan yang sama semakin meningkat curah hujan semakin meningkat pula intersepsinya.

Untuk mengetahui apakah terdapat perbedaan signifikan anatara ketiga jenis pohon dilakukan uji analisis sidik ragam (anova). Analisis keragaman intersepsi didapatkan $\mathrm{F}$ hitung $>\mathrm{F}$ tabel pada taraf nyata $a=5 \%$ sehingga adanya perbedaan yang nyata intersepsi pada jenis pohon pakoba, nantu dan cempaka, untuk mendapatakan kombinasi pengaruh terbaik maka dilanjutkan dengan uji BNT. Tabel 5 menunjukkan hasil uji BNT.
Tabel 3. Intersepsi Pada Pakoba, Nantu dan Cempaka

\begin{tabular}{ccc}
\hline Jenis Pohon & $\begin{array}{c}\text { Persentase } \\
\text { Intersepsi }\end{array}$ & Notasi \\
\hline Pakoba & $82 \%$ & $\mathrm{a}$ \\
Nantu & $86,31 \%$ & $\mathrm{ab}$ \\
Cempaka & $89,37 \%$ & $\mathrm{~b}$ \\
\hline
\end{tabular}

BNT $=18,22$

Keterangan : Notasi yang sama menyatakan tidak ada perbedaan

Hasil dari uji lanjut terlihat pada Tabel 3 dimana angka yang diikuti huruf yang sama tidak berbeda secara nyata. Jenis pohon pakoba dengan persentase intersepsi $82 \%$ berbeda nyata dengan cempaka $89,37 \%$ dan tidak berbeda nyata dengan nantu $86,31 \%$. Nantu $86,31 \%$ tidak berbeda nyata dengan cempaka 89,37\%. Tabel 5 menunjukkan pohon dengan nilai intersepsi terkecil adalah pohon pakoba yaitu $82 \%$, kemudian pohon nantu $86,31 \%$ dan nilai intersepsi terbesar adalah pohon cempaka, yaitu $89,37 \%$.

Intersepsi dipengaruhi oleh dua faktor yaitu pertama curah hujan. Besar kecilnya curah hujan dapat berpengaruh pada besar kecilnya nilai intersepsi. Faktor kedua yaitu vegetasi, yang mana vegetasi dengan tajuk yang rapat dan lebat akan menahan air hujan yang jatuh di permukaan tajuk sehingga sebagian terintersepsi dan sebagian lagi menjadi lolosan tajuk dan aliran batang (Asdak, 2014). Cempaka memiliki nilai intersepsi terbesar karena cempaka dengan model arsitektur attim, sistem percabangan monopodial dengan tata letak cabang simetris dan tersebar merata sepanjang batang mulai dari percabangan pertama sampai puncak pohon yang menghasilkan pohon yang lebat dan tajuk yang padat. Pakoba dengan model arsitektur massart memiliki bentuk tajuk yang bertingkat bila dibandingkan nantu dan cempaka pakoba dapat menghasilkan tajuk yang lebih rapat dan tebal namun, seperti penjelasan sebelumnya pakoba pada penelitian ini tidak dapat bertumbuh dan berkembang dengan lebih baik karena jarak tanam yang rapat. Bentuk tajuk dan kerapatan tajuk sangat mempengaruhi kemampuan tajuk pohon untuk menahan air hujan kemudian menguapkannya kembali melalui intersepsi. 
Cempaka dengan diameter tajuk $6,44 \mathrm{~m}$ dan luas tajuk 34,82 m lebih besar dibandingkan pakoba dan nantu hal ini menyebabkan besarnya air yang terintersepsi dan kecilnya air yang jatuh melalui aliran batang dan lolosan tajuk pada cempaka.

Nantu memiliki cabang yang simetris dan tersebar merata seperti cempaka namun nantu memiliki nilai intersepsi yang lebih rendah dari cempaka. Nantu dengan diameter tajuk 5,33 m dan luas tajuk 23,68 m masih lebih kecil dibandingkan dengan pohon cempaka oleh karena itu nilai intersepsi nantu masih lebih rendah karena masih lebih banyak air hujan yang lolos melalui aliran batang dan Iolosan tajuk. Nilai intersepsi terkecil adalah pada pakoba. Pakoba dengan percabangan condong ke atas, diameter tajuk 5,12 m dan lolosan tajuk 21,58 $\mathrm{m}$ paling kecil dibandingkan dengan cempaka dan nantu menyebabkan air hujan sangat sulit untuk tertahan di tajuk pohon untuk diuapakan, air hujan lebih mudah jatuh menjadi aliran batang dan lolosan tajuk daripada terintersepsi.

Pemilihan jenis pohon pohon memiliki peranan yang sangat penting terkait dengan konservasi air dan tanah pada suatu daerah (Hasanuddin, 2013). Menurut Arsyad (2012) konservasi air pada prinsipnya adalah penggunaan air hujan yang jatuh ke atas permukaan tanah seefisien mungkin dengan pengaturan waktu aliran yang tepat sehingga tidak terjadi banjir pada musim hujan dan tersedia cukup air pada musim kemarau. Konservasi air dan konservasi tanah merupakan dua kegiatan yang berhubungan sangat erat satu sama lainnya karena air menjadi penyebab terjadinya erosi.

Berkaitan dengan penerapan dalam konservasi tanah dan air, banjir dan erosi dipengaruhi oleh aliran permukaan. Air hujan akan mencapai permukaan tanah melalui lolosan tajuk dan aliran batang. Air hujan yang sampai ke permukaan tanah tidak semua ter-infiltrasi ke dalam tanah, melainkan sebagian mengalir sebagai aliran permukaan (run-off), aliran permukaan yang berlebihan akan menyebabkan banjir dan erosi (Irmas, 2010). Vegetasi pohon sangat berpengaruh dalam mengurangi jumlah aliran permukaan. Selama peristiwa hujan, sebagian air hujan akan ditahan oleh vegetasi sebelum mencapai permukaan tanah sebagian lagi akan menguap ke udara yang dikenal dengan intersepsi (Munandar et al, 2016). Melalui intersepsi hujan, vegetasi hutan berperan mengurangi air hujan yang menjadi aliran permukaan dan berperan menurunkan energi kinetik dan kecepatan butir air hujan untuk mencapai permukaan tanah menyebabkan kurangnya dispersi agregat tanah atau pemisahan tanah menjadi bagian yang lebih kecil sehingga tidak terjadi banjir dan erosi (Barri, 2010).Berdasarkan hasil penelitian intersepsi pada pakoba, nantu dan cempaka, vegetasi pohon yang berperan dalam konservasi air dan tanah adalah cempaka. Cempaka dengan nilai intersepsi tertinggi menyebabkan lebih sedikit air hujan yang mengalir melalui lolosan tajuk dan aliran batang sehingga tidak terjadi aliran permukaan yang berlebihan yang menyebabkan banjir dan erosi.

\section{KESIMPULAN DAN SARAN}

KesimpulanHasil penelitian ini menunjukan besarnya nilai lolosan tajuk pakoba $10,55 \%$, nantu $9,01 \%$ dan cempaka $7,99 \%$. Besarnya nilai aliran batang pakoba $8,13 \%$, nantu 5,25 \% dan cempaka $2,45 \%$. Besarnya nilai intersepsi pakoba, yaitu 82 $\%$, nantu 86,31 \% dan cempaka 89,37 \%. Berdasarkan hasil analisis keragaman yang berbeda nyata adalah interseps. Uji BNT menunjukkan jenis pohon pakoba dengan persentase intersepsi $82 \%$ berbeda nyata dengan cempaka $89,37 \%$ dan tidak berbeda nyata dengan nantu $86,31 \%$. Nantu $86,31 \%$ tidak berbeda nyata dengan cempaka $89,37 \%$.

\section{Saran}

Disarankan untuk dilaksanakan penelitian lanjutan pada curah hujan dengan besaran yang lebih besar dan kejadian hujan yang lebih banyak pada vegetasi pohon yang berbeda atau dengan vegetasi pohon yang sama tapi di lokasi yang berbeda untuk menambah informasi tentang kemampuan pohon dalam mengintersepsi air hujan yang berperan dalam konservasi air dan tanah. 


\section{DAFTAR PUSTAKA}

Arrijani., dan B. J. A. Lombok. 2006. Model Arsitektur Pohon pada Hulu Das Cianjur Zona Sub-Montana Taman Nasional Gunung Gede Pangrango. Jurnal Matematika Sains dan Teknologi, 7(2) : 7184.

Arsyad, S. 2012. Konservasi Tanah \& Air. IPB Press. Bogor.

Asdak, C. 2014. Hidrologi \& Pengelolaan Daerah Aliran Sungai. Gadjah Mada University

Basri, H., Manfarizah., dan A. Salasa. 2012. Intersepsi Air Hujan Pada Tanaman Kopi Rakyat di Desa Kebet, Kecamatan Bebesan, Kecamatan Aceh Tengah. Jurnal Floratek, 7: 91-106.

Heryansah, E. L. 2008. Intersepsi Hujan Pada Hutan Tanaman Agathis loranthifolia Sal. Di Das Cicatih Hulu Sukabumi. Departemen Geofisika dan Meteorologi. Fakultas Matematika dan IImu Pengetahuan Alam. Institut Pertanian Bogor.

Irmas. F.A. 2010.Intersepsi Aliran Batang Dan Lolosan Tajuk Pada Berbagai Jenis Pohon Di Universitas Lampung. Fakultas Pertanian. Universitas Lampung.

Jayanti, S. D., Mustafril. Dan R. Munandar. 2015. Pengembangan Model Intersepsi Pada Pohon Jati (Tectona Grandis) Dan Pohon Pinus (Casuarinas Cunninghamiana). Jurnal Agrotekno, 17(2): 32-40. 